\title{
Large branchiopods (Branchiopoda: Anostraca, Notostraca and Spinicaudata) from the salt lakes of Algeria
}

\author{
Boudjéma SAMRAOUI*, Khemissa CHAKRI and Farrah SAMRAOUI \\ Laboratoire de Recherche des Zones Humides, University of Annaba, 4 rue Hassi-Beïda, Annaba, Algeria \\ *e-mail corresponding author: bsamraoui@yahoo.fr
}

\begin{abstract}
We conducted a survey of large branchiopods (Crustacea, Branchiopoda) of the major salt lakes of Algeria, particularly those of the eastern Hauts Plateaux. The aim of the survey was to complement a previous survey that focused on the freshwater habitats of Numidia, northeast Algeria. The study revealed 8 species, with one taxon new to Algeria and North Africa (Chirocephalus salinus). Data on the status, phenology and habitats of collected and previously known species are presented for 19 taxa. The distribution of many species has been greatly extended and the co-occurrence of Artemia tunisiana and Branchinella spinosa has been recorded. The studied salt lakes, owing to a large production of fairy shrimps, support a great number of wintering and breeding waterbirds, but are subject to increasing human pressure.
\end{abstract}

Key words: Crustacea, Branchiopoda, survey, salinas, Algeria, North Africa

\section{INTRODUCTION}

Our knowledge of the distribution and ecology of large branchiopods of Algeria lags far behind that of neighbouring Morocco (Gauthier 1929; Peres 1939; Boutin 1982; Thiery \& Brtek 1985; Thierry 1986a, b, c; Roux \& Thierry 1988) despite pioneering work of Gauthier (1928a, b; 1930; 1931; 1933a, b, d; 1934 a, b) and later by Dumont et al. $(1991,1995)$ in the Sahara. In Algeria, much insight has yet to be gained from investigating unexplored parts of the country, which despite past efforts, are still imperfectly surveyed (Samraoui \& Dumont 2002). The vast complex of salt lakes in the Hauts Plateaux is a perfect case in point, as it proved to be a challenging task for Gauthier (1928a) who attempted to sample this region but failed for a variety of reasons (difficulty of access and drought). This second survey which focuses mainly on the salt lakes complex of the Eastern Hauts Plateaux, which has hardly been previously investigated, is part of an ongoing effort of the Laboratoire de Recherche des Zones Humides (L.R.Z.H., University of Annaba) to fully survey the biodiversity of the Algerian wetlands (Samraoui \& de Bélair 1997, 1998).

\section{METHODS}

A total of 38 sites, located across the coastal region (Fig. 1, $1 \& 2$ ), the Hauts Plateaux (Fig. 1, 3-5) and the Sahara (Fig. 1, 6), were sampled with a dipnet and plankton net (mesh size $=50$ microns) mainly in 2004 and 2005. Samples were kept in formaldehyde (4\%) prior to identification in the laboratory. Positions, recorded as decimals of minutes, were determined with a global Positioning System (Garmin 45; Garmin/Europe Ltd, Romsey, U.K.) that had a resolution of about $2 \mathrm{~m}$.
Other positions were taken from maps. In locality designations, the words 'Garaet' or 'Garaa', 'Sebkha' or 'Chott' are used indiscriminately for salt lake or saline pond and are abbreviated to ' $\mathrm{G}$ ', 'S' or ' $\mathrm{C}$ '. New records are noted by (!). We have followed the nomenclature for Anostraca of Belk \& Brtek (1995) and kept vouchers specimens within the reference collection of the L.R.Z.H. (University of Annaba).

\section{RESULTS}

Annotated check-list of large branchiopods of Algeria:

Order: Anostraca

1. Family: Artemiidae Grochowski

Artemia tunisiana (Linnaeus 1758)

Status and Phenology: abundant and widespread; January-July.

This study: (O.C.): salines of Arzew, (E.H.P.): G. Ezzemoul; (S): chott Merouane, chott Melghir (!).

Previous records: Temacin (Blanchard \& Richard 1890); Temacine, Mécheria, Tolga, sebkha Hamiet (Gauthier 1928a); salines of Arzew, G. Ezzemoul (cited as N'zouri), Sidi Bouziane, chott Merouane, mellaha Guerguour el-Amri (Zemmouri 1991); Touggourt (Beladjal et al. 1995)

Comments: in view of existing taxonomical problems (A. salina?) and pending studies aimed at resolving the status of North African populations (Belk \& Brtek 1995), we followed Bowen \& Sterling (1978) who assigned the status of $A$. tunisiana to North African populations. In July, at G. Ezzemoul, copulations were most frequent as temperature $(>43$ $\left.{ }^{\circ} \mathrm{C}\right)$ and water conductivity $(>200 \mathrm{mS} \mathrm{cm}$ ) rose. Noteworthy, was the co-occurrence at G. Ezzemoul of A. tunisiana and Branchinella spinosa. 


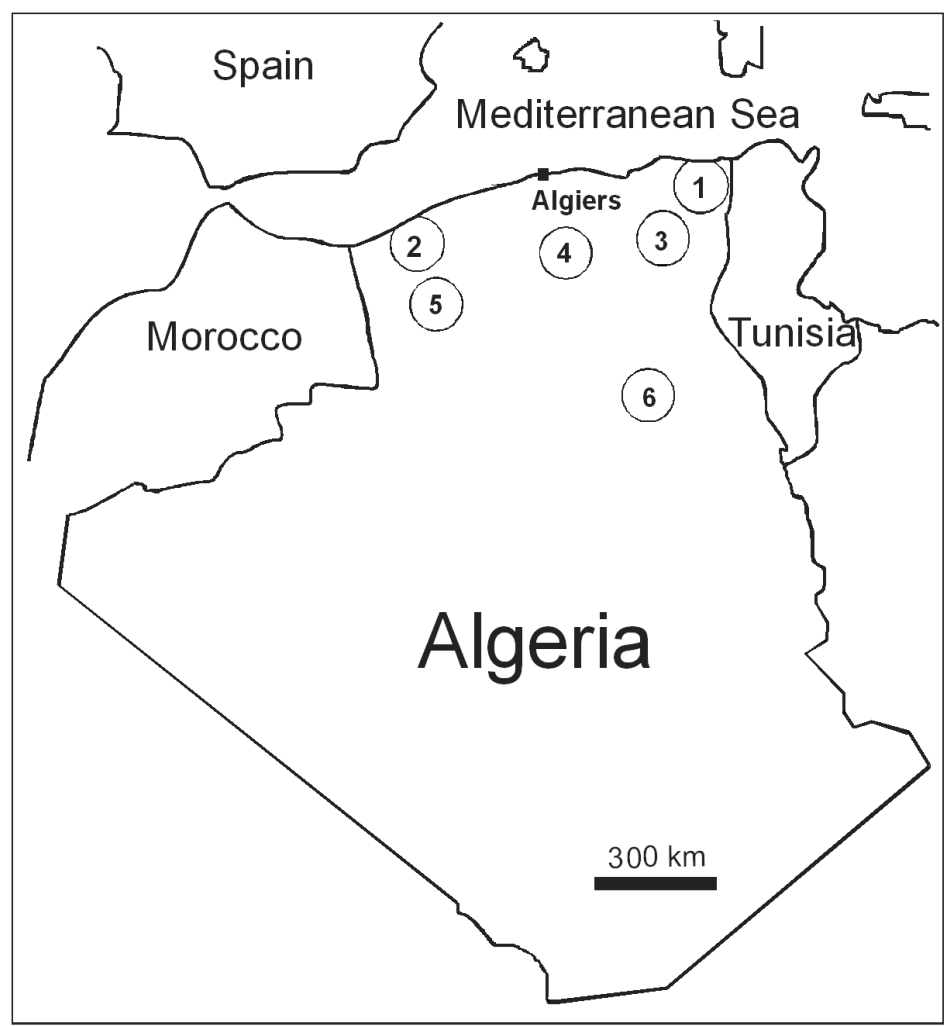

Fig. 1. Map of the sites.

1. Numidia (Num.):

1 - Les Salines $\left(36^{\circ} 50.34^{\prime} N, 7^{\circ} 47.46^{\prime}\right.$ E, alt. 2 m)

2 - Laalalig ( $36^{\circ} 50.231^{\prime} \mathrm{N}, 7^{\circ} 45.396^{\prime} \mathrm{E}$, alt. $\left.2 \mathrm{~m}\right)$

\section{Oran's complex (O.C.):}

1 - La Grande sebkha of Oran $\left(35^{\circ} \mathrm{N}, 0^{\circ} \mathrm{W}\right.$, alt. $\left.80 \mathrm{~m}\right)$

2 - Salines of Arzew ( $35^{\circ} 41.880^{\prime} \mathrm{N}, 0^{\circ} 17.082^{\prime} \mathrm{W}$, alt. $84 \mathrm{~m}$ )

3. Eastern Hauts Plateaux (E.H.P), the altitude for the whole wetlands complex lies between 900 and $1000 \mathrm{~m}$ :

1 - Garaet Tarf $\left(35^{\circ} 42^{\prime} \mathrm{N}, 7^{\circ} 08^{\prime} \mathrm{E}\right)$

2 - G. Guellif $\left(35^{\circ} 47.200^{\prime} \mathrm{N}, 7^{\circ} 00.00^{\prime} \mathrm{E}\right)$

3 - G. Ank El Djmel ( $\left.35^{\circ} 46.298^{\prime} \mathrm{N}, 6^{\circ} 52.00^{\prime} \mathrm{E}\right)$

4 - Chott Tinsilt ( $\left.35^{\circ} 53.619^{\prime} \mathrm{N}, 6^{\circ} 30.000^{\prime} \mathrm{E}\right)$

5 - G. Ezzemoul (35 53.137'N, 6 $\left.{ }^{\circ} 30.200^{\prime}\right)$

6 - G. Boucif $\left(35^{\circ} 47.211^{\prime} \mathrm{N}, 7^{\circ} 04.991\right.$ ' E)

7 - Chott Djendli (Boumia) (3542.000’N, $\left.6^{\circ} 31.554^{\prime} \mathrm{E}\right)$

8 - Tazouguert I $\left(35^{\circ} 21.04^{\prime} \mathrm{N}, 7^{\circ} 16.042^{\prime} \mathrm{E}\right)$

9 - Tazouguert II $\left(35^{\circ} 23.777^{\prime} \mathrm{N}, 7^{\circ} 19.920^{\prime} \mathrm{E}\right)$

10 - Timerganine $\left(35^{\circ} 34.655^{\prime} \mathrm{N}, 6^{\circ} 58.275^{\prime} \mathrm{E}\right)$

11 - Jemot $\left(35^{\circ} 38.708^{\prime} \mathrm{N}, 7^{\circ} 00.825^{\prime} \mathrm{E}\right)$

12 - G. Marshel ( $\left.35^{\circ} 48.528^{\prime} \mathrm{N}, 6^{\circ} 44437^{\prime} \mathrm{E}\right)$

13 - G. Boulehilet ( $\left.35^{\circ} 44.699^{\prime} \mathrm{N}, 6^{\circ} 47.431^{\prime} \mathrm{E}\right)$

14 - Zaher (a smaller chott south of G. Tarf)

\section{Central Hauts Plateaux (C.H.P.):}

1 - Chott El Hodna $\left(35^{\circ} 22.000^{\prime} \mathrm{N}, 4^{\circ} 32.513^{\prime} \mathrm{E}\right.$, alt. $\left.=390 \mathrm{~m}\right)$

2 - Chott El Zahrez (34 $57.382^{\prime}$ N, $2^{\circ} 48.838^{\prime}$ E, alt. $\left.=844 \mathrm{~m}\right)$

3 - Diar Chioukh $\left(34^{\circ} 52.413^{\prime} \mathrm{N}, 3^{\circ} 27.124^{\prime} \mathrm{E}\right.$, alt. $\left.=1125 \mathrm{~m}\right)$

4 - Boughzoul $\left(35^{\circ} 41.384^{\prime} \mathrm{N}, 2^{\circ} 50.264^{\prime} \mathrm{E}\right.$, alt. $\left.=647 \mathrm{~m}\right)$
5. Western Hauts Plateaux (W.H.P.):

1 - Chott Chergui (34 03.376' N, $0^{\circ} 05.164^{\prime}$ W, alt. $978 \mathrm{~m}$ )

2 - Sebkhat Naama $\left(33^{\circ} 17.953^{\prime} \mathrm{N}, 0^{\circ} 13.722^{\prime} \mathrm{W}\right)$

3 - Dayet El Ferd (34 $\left.30.416^{\prime} \mathrm{N}, 1^{\circ} 13.959^{\prime} \mathrm{W}\right)$

4 - Mare Oued Nachef (Sebdou): the only freshwater site sampled in this survey.

\section{Sahara (S):}

1 - Outaya reservoir $\left(35^{\circ} 7.700^{\prime} \mathrm{N}, 5^{\circ} 36.323^{\prime} \mathrm{E}\right.$, alt. $\left.=5 \mathrm{~m}\right)$

2 - Merja Hamraïa I (34ㅇ 06.223'N, $\left.6^{\circ} 14.784^{\prime} \mathrm{E}\right)$

3 - Merja Hamraïa II $\left(34^{\circ} 05.588^{\prime} \mathrm{N}, 6^{\circ} 20.667^{\prime} \mathrm{E}\right)$

4 - Chott Melghir $\left(34^{\circ} 10.631^{\prime} \mathrm{N}, 6^{\circ} 17.322^{\prime} \mathrm{E}\right.$, alt. $\left.=0 \mathrm{~m}\right)$

5 - Chott Merouane $\left(34^{\circ} 02.433^{\prime} \mathrm{N}, 5^{\circ} 58.748^{\prime} \mathrm{E}\right)$

6 - Oued Khrouf $\left(33^{\circ} 53.451^{\prime} \mathrm{N}, 6^{\circ} 01.921^{\prime} \mathrm{E}\right)$

7 - Tindla $\left(33^{\circ} 39.781^{\prime} \mathrm{N}, 6^{\circ} 02.815^{\prime} \mathrm{E}\right)$

8 - Sidi Amrane (33⒉ $\left.29.873^{\prime} \mathrm{N}, 5^{\circ} 59.380^{\prime} \mathrm{E}\right)$

9 - Merjaja, Touggourt $\left(33^{\circ} 03.432^{\prime} \mathrm{N}, 6^{\circ} 03.967^{\prime} \mathrm{E}\right)$

10 - Temacine $\left(33^{\circ} 01.044^{\prime} \mathrm{N}, 6^{\circ} 01.442^{\prime} \mathrm{E}\right)$

11 - Sidi Khouiled, Ouargla ( $\left.32^{\circ} 02.913^{\prime} \mathrm{N}, 5^{\circ} 22.139^{\prime} \mathrm{E}\right)$

12 - El Goléa $\left(30^{\circ} 31.778^{\prime} \mathrm{N}, 2^{\circ} 56.201^{\prime} \mathrm{E}\right)$ 


\section{Family: Branchinectidae Daday}

Branchinecta ferox (Milne-Edwards 1840)

Status and Phenology: unknown

This study: no record.

Previous records: Mécheria, Aïn Sefra (Gauthier 1928a).

Comments: this steppic species is apparently confined to the western part of Algeria.

\section{Family: Thamnocephalidae Packard}

\section{Branchinella spinosa (Milne-Edwards 1840)}

Status and Phenology: abundant and widespread within the salt lakes complex of the Eastern Hauts Plateaux. April-June.

This study: (E.H.P.): G. Tarf (!), G. Guelif (!), G. Ank El Djmel (!), G. Ezzemoul (!).

Previous records: Boughzoul (Beladjal et al. 1995).

Comments: the range of this species has extended further east. There is no doubt that the abundance of this species can be explained in part by the large number of resident birds in the area (Greater flamingos, Shelducks, Avocets, Black-winged Stilts, Slender-billed gulls). As noted above, it co-occurred with A. tunisiana at G. Ezzemoul.

\section{Family: Branchipodidae Daday}

\section{Branchipus schaefferi Fischer 1834}

Status and Phenology: unknown

This study: no record.

Previous records: Laghouat, Biskra (Blanchard \& Richard 1890); Daïa de Tilrempt (Daday 1910); Tassili N'Ajjer (Daday 1911; Gauthier 1928); Mécheria, El Bayadh, between El Bayadh and Aflou, between Laghouat and Djelfa, (Gauthier 1928a); O. Mzab (Gauthier 1928b); Ahaggar (Gauthier 1930); Mouydir (Gauthier 1933d); Saïda (Gauthier 1934a) Sidi Makhlouf near Djelfa (Beladjal et al. 1995).

Comments: apparently, this steppic species is widespread but is probably rare across the Eastern Hauts Plateaux where freshwater habitats are scarce.

\section{Branchipus visnyai Kertesz 1956}

Status and Phenology: unknown.

This study: no record

Previous records: Algeria (Cottarelli \& Mura 1983).

Comments: confirmation of this species is needed.

\section{Tanymastigites mzabica (Gauthier 1928)}

Status and Phenology: rare and possibly endangered. This study: no record

Previous records: O. Mzab (Gauthier 1928b).

Comments: a previous search in the Mzab (Sahara) failed to uncover this endemic species (Samraoui \& Dumont 2002).

\section{Tanymastigites perrieri (Daday 1910)}

Status and Phenology: unknown.

This study: no record.

Previous records: Daïa de Tilrempt (Daday 1910); El Bayadh (Beladjal et al. 1995).

Comments: this steppic species may also be restricted to the central and western parts of Algeria.

\section{Tanymastix stagnalis (Linnaeus 1758)}

Status and Phenology: rare with a restricted range. This study: no record.

Previous records: Numidia (Gauthier 1928a; Samraoui \& Dumont 2002), Réghaïa (Gauthier 1928a).

Comments: the status of this species, which has a restricted coastal distribution (a single site known), is a matter of great concern.

\section{Family: Chirocephalidae Daday}

\section{Chirocephalus diaphanus Prévost 1803}

Status and Phenology: abundant and widespread. November-May.

This study: (W.H.P.): Mare O. Nachef (!), Sebdou (!).

Previous records: between Soukh Ahras and Ghardimaou (Tunisia), Algiers, Derrag, Theniet El Had, Tlemcen, Saïda (Gauthier 1928a, 1934a); Numidia (Samraoui \& Dumont 2002).

Comments: a common species found in the wet and subhumid zones.

\section{Chirocephalus salinus Daday 1913}

Status and Phenology: abundant and probably widespread in coastal salinas and brackish habitats. December-March.

This study: (Num.): Les Salines (!), Mare Laalalig (!).

Previous records: none

Comments: a new addition to the Algerian and North African check-lists. Noteworthy are records of this species in freshwater habitats (Cottarelli \& Mura 1983).

\section{Branchinectella media Schmankewitsch 1873}

Status and Phenology: possibly more widespread in the western part of the country. December-February.

This study: (E.H.P.): Boumia (!), Tinsilt (!).

Previous records: Grande Sebkha d'Oran, Lac de la Sénia, Oran (Blanchard \& Richard, 1890), Lac de la Sénia, Oran, Baniou, Mécheria (Gauthier 1928a).

Comments: Daday (1910) correctly identified B. media, listed as Artemia salina by Blanchard \& Richard (1890). Our findings extend considerably to the east the range of this species within Algeria.

6. Family: Streptocephalidae Daday

Streptocephalus rubricaudatus (Klunzinger 1867) 
Status and Phenology: unknown.

This study: no record.

Previous records: Ifedil, Tassili N'Ajjer (Daday, 1911), Bei Bei near Djanet (Beladjal et al. 1995), Ouargla (Gauthier 1930).

Comments: confined to the Sahara.

\section{Streptocephalus torvicornis bucheti Daday 1910}

Status and Phenology: widespread in the Central and western parts of Algeria, September-November.

This study: (E.H.P.): Boucif (!); Jemot (!); (S): Tassili N'Ajjer (Guelta Issendilène).

Previous records: between Laghouat and Djelfa (Gauthier 1928a). Tassili N'Ajjer (Daday 1910; Gauthier, 1930); Mzab, Ahaggar (Gauthier 1930); Mouydir (Gauthier 1933d).

Comments: the range of $S$. torvicornis bucheti is extended further east but this taxon seems to have stopped short of colonizing Numidia and other coastal areas (Samraoui \& Dumont 2002).

Order: Notostraca

7. Family: Triopsidae Keilhack

Triops cancriformis simplex Ghigi 1921

Status and Phenology: widespread. September-November.

This study: (E.H.P.): Boucif(!), Jemot (!).

Previous records: Laghouat (Blanchard 1891); Mécheria, El Bayadh, between Laghouat and Djelfa (Gauthier 1928a). Guelt es Stel, Bou Gtoub, Ghardaïa, daya El Itima, south-west of Oran and near the Moroccan border (Gauthier 1934b).

Comments: this steppic species, whose range is expanded further east, is replaced by Lepidurus apus lubbocki in the wet zone (Gauthier 1928a).

Triops granarius (Gauthier 1928)

Status and Phenology: unknown.

This study: no record.

Previous records: Mouydir (Gauthier 1933d)

Comments: confined to the Sahara.

\section{Lepidurus apus lubbocki (Brauer 1873)}

Status and Phenology: locally abundant in coastal sites. This study: no record.

Previous records: Reghaïa, Oued Smar (Gauthier 1928a), Numidia (Gauthier 1928a, Samraoui \& Dumont 2002).

Comments: found only in freshwater habitats across the humid and subhumid zones.

Order: Spinicaudata

8. Family: Cyzicidae Barnard

Cyzicus tetracerus (Krynicki 1830)
Status and Phenology: widespread, scattered and never abundant. September-December.

This study: (E.H.P.): Jemot (!).

Previous records: Saïda (Gauthier 1934a); Numidia (Samraoui \& Dumont 2002).

Comments: this Euro-Asian species has also a scattered distribution in Europe (Brtek \& Thiéry 1995).

9. Family Leptestheriidae (Stebbing)

Leptestheria cortieri Daday 1923

Status and Phenology: unknown.

This study: no record.

Previous records: Tassili N'Ajjers (Cortier in Gauthier 1930); Mouydir (Gauthier 1933d).

Comments: apparently confined to the Sahara.

\section{Leptestheria mayeti Simon 1885}

Status and Phenology: unknown.

This study: no record.

Previous records: Laghouat (Blanchard 1891). Between Laghouat and Djelfa (Gauthier 1928a), Oran, ouled Sidi Brahim, Tilrempt, Mzab (Seurat 1930).

Comments: found at the northern edge of the Sahara and apparently restricted to the central and western parts of Algeria.

\section{DISCUSSION}

On the basis of material collected, 8 species could be distinguished with one new addition, Chirocephalus salinus, to the previous check-list (Samraoui \& Dumont 2002): a total of 19 species of Algerian Euphyllopods are now known, distributed in 9 families and 13 genera. The present study also improved our knowledge of the distribution of large Branchiopods within Algeria with a special emphasis on the Eastern Hauts Plateaux.

There is little doubt that these numbers will increase in future as vast areas of Algeria have yet to be adequately sampled and, due to the size of the country, a considerable effort is needed to bring our knowledge in line with that of neighbouring Morocco. More samples are needed from the steppic region (annual rainfall less than $300 \mathrm{~mm}$ ), which unfortunately was experiencing a severe drought during our survey, and the Sahara before a true picture of the distribution of the large branchiopods of Algeria can emerge. These regions, as experienced already by Gauthier (1928a), are particularly difficult to survey as periods of drought can extend over several years.

The most diverse group of large branchiopods in Algeria is made up of the Anostraca with 13 species and 6 families. Our survey includes five species Branchinella spinosa, Branchinectella media, Streptocephalus torvicornis bucheti, Triops cancriformis and Cyzicus tetracerus, new to the Eastern Hauts Plateaux. The former is the most abundant and widespread species of Euphyllopods in the region. 
Gauthier's $(1928 \mathrm{a} ; 1930 \mathrm{a})$ data prompted him to explain the distribution of North African Entomostraca by fitting them into 3 climatic belts: wet, substeppic and steppic but this author did not assign any large branchiopod to the substeppic zone, suggesting that the fauna of this climatic belt would be made up of a mixture of species from the wet zone and the steppic zone. Our results differ slightly with this scheme: with an annual rainfall of less than $500 \mathrm{~mm}$ (Seltzer 1946), the eastern Hauts Plateaux belong clearly to the substeppic zone (amount of rainfall between 300 and $500 \mathrm{~mm}$, according to Gauthier's classification). Yet, characteristic species of both the wet zone (Chirocephalus diaphanus and Lepidurus apus lubbocki) and the steppic zone (Branchipus schaefferi, Branchinecta ferox, Leptestheria mayeti) were apparently absent from the area. Only Streptocephalus torvicornis and Triops cancriformis simplex, assigned by Gauthier (1928a) to the steppic zone were present. The salt lakes of the Eastern Hauts Plateaux and, the substeppic zone as a whole, seem to be mostly characterised by the presence of two large branchiopods: Branchinella spinosa and Branchinectella media.

The presence of Streptocephalus torvicornis bucheti in the eastern Hauts Plateaux highlights even more its absence from Numidia, northeast Algeria. The western part of the Maghreb may have acted as an African glaciation refuge and three main reasons might explain the failure of this species to colonise Numidia and Europe in the Holocene ( $c a$ 18000-12000 BP), during the eustatic lowering of the Mediterranean, via the strait of Sicily: first, the subtropical climate of Numidia could not conceivably be inadequate for this warm stenotherm species (Dumont et al. 1995). Second, Streptocephalus torvicornis may have been excluded through competition by Chirocephalus diaphanus, C. salinus or Tanymastix stagnalis, already present there. Third, Numidia is relatively isolated when one looks at the migration and movement pattern of waterbirds associated with salt lakes. For example, the Greater Flamingo Phoenicopterus roseus rarely stops in Numidia between the Eastern Hauts Plateaux and southern Europe. The exchanges with the Eastern Hauts Plateaux are mostly dominated by direct vertical movements from northeastern Saharan salt lakes or with southern France and Italy, and by horizontal movements between Algerian and Tunisian salt lakes (unpublished). Transient populations of $S$. torvicornis torvicornis (thus not originating from the Maghreb) which were found in a small island in the Mediterranean (Mura \& Cottarelli 1998) might have stemmed from zoochory via a distinct (eastern) flyway (Dumont 1995; Samraoui \& Dumont 2002).

A problem in the study of descriptive ecology is the difficult interpretation of structuring factors and their interactions. Resource partitioning and abiotic factors, such as temperature and salinity, are known to structure the distribution of large branchiopods (Moscatello et al.
2002; Thiéry \& Puente 2002). Although, Artemia tunisiana and Branchinella spinosa co-occurred at $\mathrm{G}$. Ezzemoul, we noted that within the salt basins, where salinity was probably higher, the former was dominant. Outside the basins, and in close proximity to inflow of freshwater, the latter was dominant. Elsewhere, across the salt lake, both species seemed to mix freely. Branchinella spinosa disappeared in June whereas Artemia cf. tunisiana lasted till July when temperature and salinity were extreme. These results are in line with reports of co-occurring Artemia parthenogenica and Branchinella spinosa with the former restricted to a higher salinity range (40 to $>100 \mathrm{gl}-1)$ and the latter confined to lower salinities (30-70 gl-1) (Thiéry \& Puente 2002).

\section{CONSERVATION}

Our survey shows that two species Tanymastix stagnalis and Tanymastigites mzabica are extremely rare in Algeria, having been found in only a single site each. Efforts are urgently needed to afford protection to salt lakes, which are threatened by agriculture and pollution. Salt lakes are essential stopover and wintering sites for migrating birds and their major importance as waterbird breeding sites may have been overlooked (Saheb et al. 2006; Samraoui et al. 2006). A better understanding of the values of temporary ponds, another key habitat so far neglected at all levels, would strengthen the conservation of many endemic (like the newt Pleurodeles poireti) or endangered species besides large branchiopods. The fact that a sizable proportion of the Euphyllopods of Algeria is found in arid or semiarid parts of the country, where pressure for development is lesser than in the coastal area, might be viewed as positive. However, cases like that of Tanymastigites mzabica is symptomatic and is a cause for concern. Thus, a systematic survey of the steppic and Saharian regions of Algeria can significantly further our knowledge of this ancient and fascinating group.

\section{ACKNOWLEDGEMENTS}

We are most grateful to two anonymous referees for instructive comments on a previous version of the manuscript.

\section{REFERENCES}

Beladjal, L., J. Mertens \& H.J. Dumont. 1995. An analysis of the setation pattern of the limbs in Anostraca (Crustacea); using the Algerian species as an example. Hydrobiologia, 298: $263-280$

Belk, D. \& J. Brtek 1995. Checklist of the Anostraca. Hydrobiologia, 298: 315-353.

Blanchard, R. 1891. Résultats d'une excursion zoologique en Algérie. Mém. Soc. Zool. France, 4: 208-245.

Blanchard, R. \& J. Richard. 1890. Sur les crustacés des Sebkhas et des chotts d'Algérie. Bull. Soc. Zool. France, 45: 136-138. 
Boutin, C. 1982. Données nouvelles sur la répartition et l'écologie des Notostracés du Maroc (Crustaces, Branchiopodes). Bull. Fac. Sci. Marrakech, 1: 1-7.

Bowen, S.T. \& G. Sterling. 1978. Esterase and malate dehydrogenase isozyme polymorphisms in 15 Artemia populations. Comp. Biochem. Physiol., 61B: 593-595.

Brtek, J. \& A. Thiery. 1995. The geographic distribution of the European Branchiopods (Anostraca, Notostraca, Spinicaudata, Laevicaudata). Hydrobiologia, 298: 263-280.

Cottarelli, V. \& G. Mura 1983. Anostraci, Notostraci, Concostraci. Consiglio Nazionale Delle Ricerche, Italy: 72p.

Daday, E. von. 1910. Monographie systématique des Phyllopodes Anostracés. Ann. Sci. Nat. Zool. (9), 11: 91-489.

Daday, E., von. 1911. Quelques phyllopodes Anostracés nouveaux. Ann. Sci. Nat. Zool. (9), 12: 241-264.

Daday, E., von. 1915. Monographie systématique des Phyllopodes Conchostracés. Ann. Sci. Nat. Zool. (9), 20: 39-330.

Dumont, H.J., C. De Walsche C. \& J. Mertens. 1991. Distribution and morphological variation of Streptocephalus torvicornis (Waga, 1842) in North Africa. Hydrobiologia, 212: 203-208.

Dumont, H.J., J. Mertens \& A.M. Maeda-Martinez. 1995. Historical biogeography and morphological differentiation of Streptocephalus torvicornis (Waga) since the WürmIII-glaciation. Hydrobiologia, 298: 281-286.

Gauthier, H. 1928a. Nouvelles recherches sur la faune des eaux continentales de l'Algérie et de la Tunisie. Minerva, Alger.

Gauthier, H. 1928b. Description de Tanymastix mzabica, nouveau phyllopode anostracé du Sahara et liste des Anostracés récoltés récemment par l'auteur en Algérie et en Tunisie. Bull. Soc. Hist. Nat. Afr. N., 19: 87-91.

Gauthier, H. 1929. Phyllopodes et Cladocères des collections de l'Institut Scientifique Chérifien. Bull. Soc. Sc. Nat. Maroc, 9: 72-76.

Gauthier, H. 1930. Mission Saharienne Augieras-Draper, 1927-1928. Cladocères, Ostracodes, Phillopodes Anostracés et Conchostracés. Bull. Mus. Hist. Nat. Paris, 2: 92-116.

Gauthier, H. 1931. Faune aquatique du Sahara central. Récoltes de M. Seurat au Hoggar. Bull. Soc. Hist. Nat. Afr. N., 22: 350-400.

Gauthier, H. 1933a. Nouvelles recherches sur la faune des eaux continentales de l'Algérie et de la Tunisie. Bull. Soc. Hist. Nat. Afr. N., 24: 63-68.

Gauthier, H. 1933b; Note sur certains Conchostracés de l'Algérie et de la Tunisie. Bull. Soc. Hist. Nat. Afr. N., 23: 117-126.

Gauthier, H., 1933c. Sur un Apus du Sahara central. Bull. Soc. Hist. Nat. Afr. N., 24: 87-92.

Gauthier, H. 1933d. Faune aquatique du Sahara central. Récoltes de M. Th. Monod dans l'Emmidir et l'Ahnet. Bull. Soc. Hist. Nat. Afr. N., 24:127-132.

Gauthier, H. 1934a. Nouvelles recherches sur la faune des eaux continentales de l'Algérie et de la Tunisie. 4ième note. Bull. Soc. Hist. Nat. Afr. N., 25: 121-126.

Gauthier, H. 1934b. Contribution à l'étude de l'Apus cancriformis et de ses variations dans l'Afrique du Nord (Euphyllopode Notostracé). Bull. Soc. Sc. Nat. Maroc, 14: 125-129.

Moscatello, S., G. Belmonte \& G. Mura 2002. The cooccurrence of Artemia parthenogenetica and Branchinella spinosa (Branchiopoda: Anostraca) in a saline pond of south eastern Italy. Hydrobiologia, 486: 201-206.

Mura, G. \& V. Cottarelli 1998. On the occurrence of Streptocephalus torvicornis Waga 1842 (Crustacea, Anostraca) on a coastal island off Italy. Hydrobiologia, 367: $15-19$.

Peres, J. M. 1939. Contribution à la connaissance des Notostracés du Maroc. Bull. Soc. Sc. Nat. du Maroc, 19: 23-33.

Roux, Ph. \& A. Thiéry 1988. Complément à la répartition des Crustacés Branchiopodes Anostraca, Notostraca et Conchostraca du Maroc: Le Maroc oriental. Bull. Soc. Hist. Nat. Toulouse, 124 : 225-233.

Saheb, M., M. Boulkhssaïm, A. Ouldjaoui, M. Houhamdi \& B. Samraoui (2006). Sur la nidification du Flamant rose Phoenicopterus roseus en 2003 et 2004 en Algérie. Alauda, 74: 368-371.

Samraoui, B. \& G. de Bélair 1997. The Guerbes-Senhadja wetlands: Part I. An overview. Ecologie, 28: 233-250.

Samraoui, B. \& G. de Bélair 1998. Les zones humides de la Numidie orientale: bilan des connaissances et perspectives de gestion. Synthèse 4: 1-90.

Samraoui, B. \& H.J. Dumont 2002. The large branchiopods (Anostraca, Notostraca and Spinicaudata) of Numidia (Algeria). Hydrobiologia, 486: 119-123.

Samraoui, B., A. Ouldjaoui, M. Boulkhssaïm, M. Houhamdi, M. Saheb \& A. Béchet. 2006. The first recorded reproduction of the Greater Flamingo Phoenicopterus roseus in Algeria: behavioural and ecological aspects. Ostrich, 77: 153-159.

Seltzer, P. 1946. Le climat de l'Algérie. Imp. La Typo-Litho et J. Carbonel, Algiers.

Seurat L.G. 1930. Exploration zoologique de l'Algérie de 1830 à 1930. Masson \& Cie, Paris.

Thiéry, A. 1986a. Les crustacés Branchiopodes (Anostraca, Notostraca et Conchostraca) du Maroc occidental. I. Inventaire et répartition. Bull. Soc. Hist. Nat., Toulouse, 122: 145-155.

Thiéry, A. 1986b. Linderiella africana n.sp., premier représentant des Linderiellidae (Branchiopoda Anostraca) en Afrique du Nord (Maroc). Crustaceana, 51: 155-162.

Thiéry, A. 1987. Les crustacés branchiopodes Anostraca, Notostraca \& Conchostraca des milieux limniques temporaires (dayas) au Maroc. Taxonomie, biogéographie, écologie. Doctoral dissertation, Aix-Marseille University, France.

Thiéry, A. 1991. Multispecies coexistence of Branchiopods (Anostraca, Notostraca and Spinicaudata) in temporary ponds of Chaouia plain (western Morocco): sympatry or syntopy between usually allopatric species. Hydrobiologia, 212: 117-137.

Thiéry, A. \& J. Brtek 1985. Tanymasgites jbiletica n. sp. from Morocco. (Anostraca, Branchipodidae). Annot. Zool. Bot. Bratislava, 164: 1-4.

Thiéry, A. \& L. Puente 2002. Crustacean assemblage and environmental characteristics of a man-made solar saltwork in southern France, with emphasis on anostracan (Branchiopoda) population dynamics. Hydrobiologia, 486: 191-200.

Zemmouri, A. 1991. A note on the genus Artemia in Algeria. Hydrobiologia, 212: 231-233. 